\title{
An Important Milgram-Holocaust LiNKAGE: FoRMAL RATIONALITY
}

Nestar Russell

Abstract. After Stanley Milgram published his Obedience to Authority baseline experiment, some scholars drew parallels between his findings and the Holocaust - the so-called Milgram-Holocaust linkage. However, because Milgram's research has been shown to differ in many ways from the Holocaust's finer historical details, recent literature has challenged the linkage. This article argues that the Obedience studies and the Holocaust share two commonalities that are so significant that they may negate the importance others have attributed to the differences. These commonalities are (1) an end-goal of maximising "ordinary" people's participation in harm infliction and (2) a reliance on formally rational techniques of discovery to achieve this end-goal. Using archival documents, this article reveals the learning processes Milgram utilised during his pilot studies in order to maximise ordinary people's completion of the baseline experiment. This article then illustrates how certain Nazis relied on the same techniques of discovery during the invention of the Holocaust. In effect, during the Obedience studies and the Holocaust processes were developed that made, in each case, the undoable doable.

Keywords: Formal rationality; Holocaust; Obedience; Milgram; Weber; Ritzer

Résumé. Après que Stanley Milgram eut publié les résultats de son expérience phare sur la soumission à l'autorité (Obedience to Authority), certains spécialistes ont établi un parallèle entre son étude et l'Holocauste (le présumé lien Milgram-Holocauste). Toutefois, puisque l'expérience de Milgram divergeait de nombreuses façons du contexte historique précis de l'Holocauste, la recherche récente a remis en question ce lien. Le présent article soutient que l'Holocauste et les études sur l'obéissance partagent deux points communs essentiels qui ont le pouvoir de réfuter l'importance accordée aux différences. Ces similitudes sont (1) l'objectif ultime de maximiser la participation de gens " ordinaires » dans l'infliction de la souffrance et (2) un appui sur des techniques de rationalité formelle dans l'atteinte de cet objectif ultime. En se basant sur des documents d'archives, cet article révèle les procédés d'apprentissage utilisés par Milgram durant ses études pilotes afin de maximiser la coopération de gens ordinaires à l'aboutissement de l'expérience. L'article démontre ensuite comment certains nazis ont utilisé les mêmes techniques durant l'élaboration de l'Holocauste. En

(C) Canadian Journal of Sociology/Cahiers Canadiens de sociologie 42(3) 201726 
effet, durant l'Holocauste et les études sur l'obéissance, des procédés ont été développés de part et d'autre pour faire advenir l'impensable.

Mots-clés : rationalité formelle; Holocauste; obéissance; Milgram; Weber; Ritzer

\section{INTRODUCTION}

2 tanley Milgram's Obedience to Authority research is perhaps "the most widely cited and provocative set of experiments in social science" (Miller 1986:1). In his first "remote" baseline experiment, Milgram demonstrated that nearly two-thirds (65\%) of "ordinary" Americans were willing to follow orders to inflict what they were led to believe were potentially lethal electric shocks on an innocent person (1974:6). Just like many Germans after WW2, Milgram's participants often later claimed they were "just following orders." Miller (2004:194) termed purported behavioural similarities or parallels like this between Milgram's participants, on the one hand, and ordinary Germans during the Holocaust, on the other, the "Milgram-Holocaust linkage".

Throughout the 1970s and 1980s, although some disagreed, many commentators saw merit in various scholars' actually numerous Milgram-Holocaust linkages, with some believing he essentially captured the Holocaust in the controlled laboratory setting (see Russell, 2009:114). By the 1990s, however, even proponents of Milgram's research started questioning the Holocaust connection (Blass 1993; Lutsky 1995). From the mid-1990s, this critical trend accelerated with much research listing numerous differences between the Holocaust and Obedience studies (see Russell and Gregory, 2015:129). For example, researchers noted that unlike Milgram's participants, Hitler's ordinary Germans encountered a propaganda campaign, despised their victims, volunteered to harm, acted with enthusiasm, engaged in excesses, and afterwards rarely expressed remorse. Thus, Milgram's experiments differed to the Holocaust in kind, not degree. Despite the changing tide of opinion, documents from Milgram's archive reveal a new Milgram-Holocaust linkage.

While this article does not dispute the numerous differences separating the Holocaust from Milgram's Obedience studies, it does argue that both events share two commonalities - actually necessary requirements - that are so significant they may negate the importance attributed to the historical differences. These are (1) an end-goal of maximising "ordinary" people's participation in harm infliction and (2) a reliance on formally rational techniques of discovery to achieve this end-goal. 
In presenting this Milgram-Holocaust linkage, this article is divided into three sections. The first section presents an overview of formal rationality. The second delineates Milgram's reliance on formally rational techniques of discovery during his unpublished pilot studies. The final section illustrates that certain Nazis also relied on formally rational techniques of discovery to maximise the participation of ordinary Germans during the so-called Holocaust by bullets. The aim of this article is to illustrate how both Milgram and the Nazi regime relied on formal rationality to achieve their shared goal to promote broad participation in harm infliction.

\section{Formal Rationality}

Max Weber conceives formal rationality as the search for the optimum means to a given end - the "one best way" to goal achievement. Weber's model of a formally rationalised strategy was bureaucracy, an organization designed to find the best way to goal achievement. To construct the 'one best' bureaucratic process, managers break an organisational goal into a variety of discrete tasks, the achievement of which they allocated to different functionaries or bureaucrats. Using a predetermined sequence, each bureaucrat performs their specialist task following certain rules and regulations, after which the next bureaucrat performs their specialist task until the goal is achieved.

The specific rules and regulations each bureaucrat follows are determined by what recent history suggests is probably the one best way to goal achievement. That is, as bureaucrats perform particular tasks, increasing time and observational experience leads to the incremental discovery of even better strategies, generating new and more efficient rules and regulations. Weber's characteristics of bureaucracy (as an ideal type) include: specialised labour, a well-defined hierarchy, clearly defined responsibilities, a system of rules and procedures, impersonality of relations, promotion based on qualifications, the centralisation of authority, and written records (Gerth and Mills 1946:196-204).

Building on Weber, Ritzer (1996) argues that organisational strategies like bureaucracy have four main components: efficiency, predictability, control, and calculability (E.P.C.C.). Efficiency is the pursuit of a shorter or faster route - the optimal means to a desired end. Predictability is the application of standardisation - a movement toward all variables operating in a foreseeable way that increases the ability to anticipate and plan for future outcomes. Control provides manipulative command over all factors and therefore the elimination of as many uncertainties as pos- 
sible. Greater control enables greater predictability (especially as less predictable human labour is replaced by more controllable, predictable, and efficient non-human technologies). Finally, calculability involves the quantification of as many factors as possible. Advances in calculability enables measurement, which extends control over more variables, and in turn improves the predictability of future outcomes. The greater the degree of formal rationality (E.P.C.C), the greater the chance of discovering the "one best way," and the more likely of organisational goal achievement, whatever it might be.

The one best way of producing motor vehicles over the past century or so provides an excellent example of advancing E.P.C.C. The production of the first-ever cars involved a few skilled tradespeople laboriously constructing then attaching handcrafted parts to a stationary frame. This technique was not only slow (inefficient) but also unpredictable as the variable, non-standardised parts ensured an equally variable end-product. Furthermore, because the tradespeople's skills were rare, they could resist management's coercive attempts to work faster by threatening to quit or go on strike (uncontrollable). Because control and predictability were low, management struggled to calculate daily, monthly, and annual production outputs. Thus E.P.C.C. in relation to the one best way of manufacturing cars was low.

Then Henry Ford invented the inherently bureaucratic motor car assembly-line production process. In Ford's factory, a line of vehicle frames moved along a conveyor belt. The frames moved past a line of specialist assembly workers, each of whom sequentially attached a standardised car part. At the end of the moving line a constant flow of assembled vehicles emerged. Ford's moving line caused production efficiency to greatly increase. Standardised parts meant identical products, thus predictability also increased. The set speed of the moving line enabled Ford to quantify daily, monthly, and annual output, thus increasing calculability. Control perhaps advanced the most. If one worker failed to keep up with the speed of the moving line, to the frustration of other workers and management alike, a bottleneck could form. Therefore, the set speed of the moving line in conjunction with a fear of falling behind pushed workers to work faster than they probably would of their own accord. The assembly line is therefore an early example of a more efficient non-human technology capable of imposing greater workforce control - all felt pushed by an unsympathetic machine to keep up (Ritzer 2015:37). And if workers resisted the set speed of Ford's moving line (by quitting or going on strike), because they were unskilled, he could easily replace them. Ford's "one best way" of producing cars increased all four components of a formally rational system. 
It transpires Ford developed this revolutionary system through observational experience gathered over time. That is, time and experience supplied Ford with new and potentially more effective "one best ways" of ensuring goal achievement- better rules and regulations for workers to follow. Ford was supplied with new ways of doing things until he settled on what emerged as the one best way. But rationalization did not stop there. Because workers' tasks were purposefully simple, advances in technology rendered their labour susceptible to replacement. By the end of the twentieth century, the automation of the car industry had taken Fordism to new heights, substituting (where possible) human labour with computer-guided, high-tech robots. These robots could be programmed (calculability) to perform the same tasks without variation (predictability), with no risk of labour disputes (control), and without a break at higher speeds (efficiency). As the history of car production illustrates,

Organizations have historically gained control over employees...through increasingly effective technologies. Eventually, they began reducing workers' behavior to a series of machinelike actions. And once employees were behaving like machines, they could be replaced with actual machines. The replacement of humans by machines is the ultimate stage in control over people... (Ritzer 2015:120)

Implied here is that perhaps the greatest threat to a desired end is human labour - that is, people. Humans are notoriously unpredictable, because, unlike non-human technology, they are difficult to control (Ritzer 2015:128).

So how is formal rationality, bureaucracy, E.P.C.C, and finding the "one best way" applicable to Milgram's Obedience studies? Scholars have long puzzled over how 65 per cent of participants in Milgram's baseline experiment could have inflicted ostensibly excruciating shocks on innocent people. To better understand this finding, I argue that it is important to review not just the end result but also the start-to-finish, step-by-step journey Milgram travelled to get it (Russell 2009; 2011). My review of archival documents shows that Milgram behaved less like a social scientist in constructing his experiments and more like a goalorientated project manager trying to socially engineer a preconceived result. That is, over time and through experience Milgram invented a basic procedure - the most efficient "one best way" - for the experimenter (an actor) to control participants into doing what he (Milgram) wanted: to (ostensibly) inflict harm on another person. 


\section{The Invention Of The Obedience Experiments}

During the Nazi war crimes trials, many ordinary Germans argued that they just following orders to inflict harm. This justification caused Milgram to wonder what would happen if he ran a social psychology experiment where ordinary people were instructed to follow orders to hurt another person. For such an experiment to garner scholarly attention Milgram knew it would have to obtain eye-catching results (nobody would be surprised by a low rate of obedience to hurt an innocent person). He began with a preconceived goal: to run an experiment that would "maximize obedience" (quoted in Russell 2009:64-65). Because Milgram did not have an experimental procedure capable of producing such a result, he had to invent one.

Milgram's first attempt at inventing a procedure capable of maximising obedience was rudimentary. Because many Nazi war criminals mentioned they pledged obedience to Hitler, Milgram's initial idea was to hire an actor to play an authority figure who would solicit participants to "pledge to obey" his orders (quoted in Russell 2011:148). The experimenter would then reveal his orders: participants were to physically assault another person. As Milgram said: "We can then start out by giving the subject commands from the lower end. (Tap him.) And gradually proceed to more intensive commands. (Slug him)." (Stanley Milgram Papers [hereafter SMP], Box 46, Folder 165, circa 1960).

But was a "pledge to obey" a command to (eventually) "[s]lug" another person likely to end in the goal of maximising obedience? Two limitations appeared. First, the Nazi-sounding pledge to obey was likely to alert participants to the study's actual research question. Second, putting aside the ethical and logistical difficulties of running an experiment in which innocent people were physically beaten(!), surely participants would feel too closely connected to, and thus responsible for, the disturbing end results of following orders. Milgram required a more opaque institutional justification for hurting another person, along with a more disconnected, less responsibility-inducing, means of inflicting harm. Milgram must have (perhaps intuitively) sensed both obstacles, because in his research notes solutions to them emerged. 
Figure 1: A document by Milgram titled "Studies in Obedience" (Russell 2011:148).

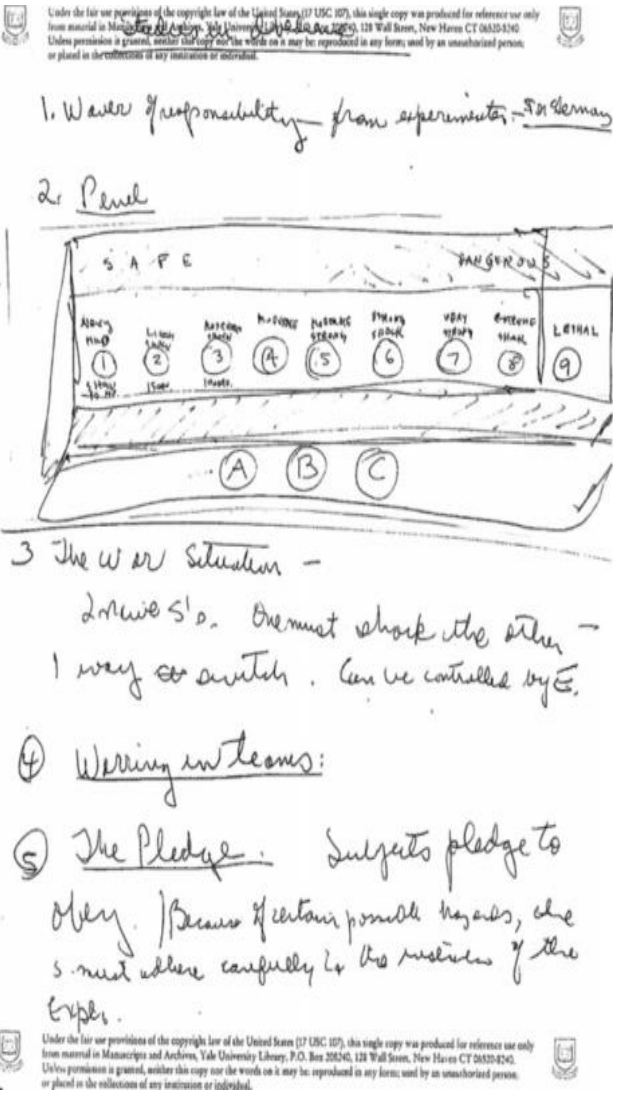

Milgram's notes (circa 1960) reveal a decision to use a shock generator panel (Figure 1). At this stage, Milgram maintained his Nazi-like "pledge to obey" (see " 5 " above), but by October 1960 he had dropped the idea in favour of a much less transparent institutional justification for inflicting harm. Now the participant in the role of a 'teacher' would inflict shocks on a 'learner' to determine if punishment improved learning (Russell 2011:150). With his shock machine and a less transparent institutional justification for inflicting shocks, Milgram had envisioned two essential components enabling him to obtain his preconceived result (Russell 2009:50-69).

To see if his research idea worked in November 1960 Milgram tasked his students with running the first Obedience study pilot. The layout of the laboratory resembled Figure 2. 
Figure 2: Milgram's sketch of the student-run pilots (SMP, Box 17, Folder 246, dated "1960").

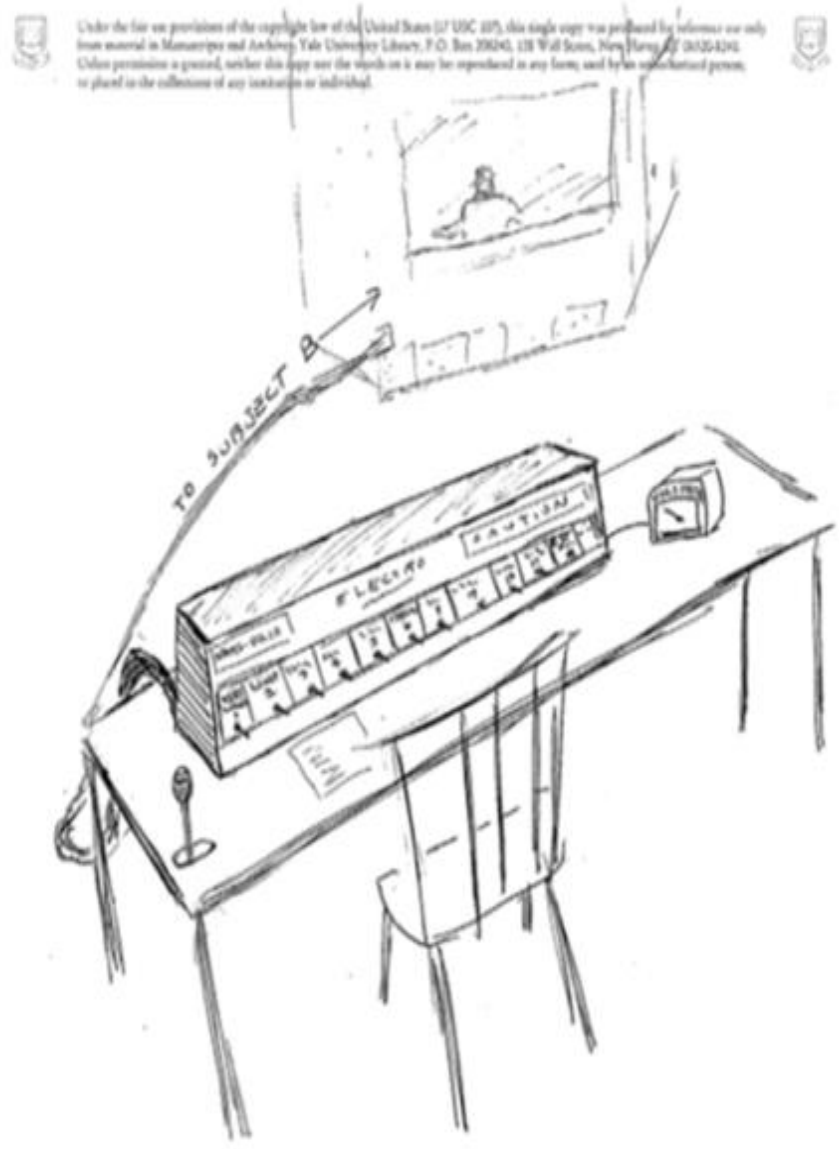

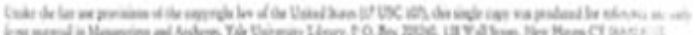

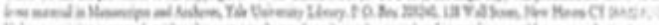

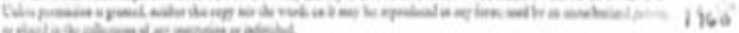

During the student-run pilots, participants could see the "shocked" learner through a translucent screen (see Figure 2). "When the very first experiments were carried out... about 60 percent of them were fully obedient" (Milgram, 1973:64). 
During the first pilots Milgram observed a strange behaviour: some participants found inflicting the shocks stressful, so in order to be able to continue to do as they were told they started looking away from the learner. Doing so seemed to make it easier for these participants to inflict every shock. For Milgram, this observation stimulated what proved to be a powerful change in procedure: substituting a solid wall for the translucent screen mitigated participant stress, thereby ensuring an even greater completion rate.

On completing the first pilots, Milgram did "not believe that the students could fully appreciate the significance of what they were viewing" (quoted in Blass 2004:68). He knew, however, that the pilot tested a variety of variables he suspected may have played some role in producing the Holocaust. In other words, what the students regarded as a fascinating spectacle, Milgram sensed might provide insight into the perpetration of the Holocaust. It was probably then that Milgram sensed the enormous potential of his research idea. Jewish himself, and/or untenured in Yale University's competitive research environment, he came to believe that officially pursuing the Obedience research programme was necessary. But in doing so, wouldn't both he and his research team (research assistants, technicians, and actors) become complicit in the unethical infliction of harm, in the form of intense stress, on innocent participants?

By the beginning of August 1961, Milgram had hired his research team and completed a second and more professional series of pilot studies. He had also persuaded all of his helpers that, despite any ethical reservations they might hold, it was important (necessary?) to inflict stress on the participants in order "to understand and conquer the disease" of "destructive obedience" (quoted in Russell 2009:104). During the final variation of the second pilot series, Milgram and research assistant Alan Elms ran the "Truly Remote Pilot study," wherein having introduced a solid wall into the basic procedure, participants could neither see nor hear the learner's reactions to being "shocked". Milgram's hypothesis about the effect of a wall proved correct, because in this pilot "virtually all" participants inflicted every shock (1965:61). Time and observational experience had led him to the one best way. The leap from a 60 per cent completion rate in the studentrun pilots to something approaching 100 per cent in the Truly Remote Pilot saw Milgram achieve his preconceived goal of maximising obedience.

Milgram had invented a procedure that, should he use it as his first official experiment, he knew was likely to generate the high rate of obedience he desired. However, an official baseline experiment 
ending in nearly all participants completing raised an unanticipated problem.

This deprived us of an adequate basis for scaling obedient tendencies. A force had to be introduced that would strengthen the subject's resistance to the experimenter's commands, and reveal individual difference in terms of a distribution of break-off points. (Milgram 1965:61)

With the intention of reducing (slightly) the completion rate by increasing participant stress, Milgram decided that the first official baseline experiment would include some auditory perceptual feedback. That is, after the participant inflicted the 300 and 315 -volt shocks the learner (who was only pretending to receive shocks) would kick the wall and then fall silent. In contrast with Milgram's repeated approach to reduce participant tension (and increase their probability of inflicting every shock), the intention behind this procedural adaptation was to increase slightly their stress levels. Having increased participants' stress levels, he presumed the overall completion rate would drop slightly.

On 7 August 1961 Milgram ran his first official baseline experiment, producing a 65 per cent completion rate. Milgram was probably expecting a higher rate considering he made only subtle changes (infrequent wall-banging) to the Truly Remote Pilot. Nevertheless, the still-surprisingly-high completion rate, which garnered much media attention, became his "best-known result" and thus had its intended effect (Miller 1986:9). Then, in an attempt to develop a theory capable of explaining the baseline result, Milgram undertook twentytwo slight variations, the fifth of which he made his "New Baseline." Unlike its predecessor, in the New Baseline the learner's intensifying verbal reactions to being 'shocked' could be heard by the participant up until the 330-volt switch (thereafter becoming silent). The more disturbing (eye-catching?) New Baseline also obtained a 65 percent completion rate and went on to serve as the basic model for all subsequent variations. Milgram anticipated that these variations would isolate what caused most participants to complete the baseline condition.

In order to efficiently process the experimental programme's 780 participants (Perry 2012:1), Milgram designed an inherently bureaucratic organisational process. Each prospective participant had to select one 60-minute slot. When participants arrived at the laboratory to fill their slot, they were processed. Processing involved Milgram's research team undertaking specialist tasks that included training participants, running the experiment, collecting data, and debriefing. Like working on an assembly line, Milgram's staff had to complete all of 
these tasks within 60 minutes so that the stage, so to speak, could be reset before the next participant's arrival at the top of the hour. The calculability inherent in this schedule enabled Milgram (on 17 October 1961) to predict that at the "end of the Spring term, 1962" data collection would end (SMP, Box 43, Folder 127). The last participant was duly processed on 27 May 1962. Finally, Milgram's bureaucratically organised research programme and the division of labour inherent to it (first link Milgram instructed second link experimenter to push third link participant into shocking final link learner) involved all of Weber's characteristics of bureaucracy (Russell 2014).

In light of all this, I argue that Milgram's research journey to the first official baseline experiment reveals the application of formally rational thought, bureaucracy, E.P.C.C., and the pursuit of the 'one best way' to goal achievement. I argue this because after Milgram introduced his more "calculable" non-human shock technology and having undertaken numerous pilot runs, he gained increasing "control" over the likely official baseline completion rate. Indeed, Milgram gained so much control that before running the first official experiment he was able to roughly "predict" the likely results - most participants would inflict every shock. After running the Truly Remote Pilot Milgram had discovered the most "efficient" means of arriving at his preconceived end.

Furthermore, in order to process the enormous number of participants, Milgram designed and relied upon an inherently bureaucratic organisational process. It could be argued that the non-human technology of this assembly line process played a role in pushing the research assistants, actors, participants, and perhaps even Milgram himself into keeping up with the set schedule.

But in terms of the baseline procedure, it appears Milgram had learnt how to socially engineer his preconceived goal whereby after running the Truly Remote Pilot he was able to ensure that during the first official baseline experiment most ordinary people would (ostensibly) inflict serious harm on others. In fact, this was the conclusion of Edward E. Jones, a reviewer of Milgram's (1963) first baseline condition paper, who rejected it on the grounds the study was at best a "triumph of social engineering" (quoted in Parker 2000:112).

The following section argues that certain Nazis travelled a similar formally rational journey of discovery to ensure most ordinary Germans would likewise inflict harm on others, thus illustrating what I believe to be the most important Milgram-Holocaust linkage. 


\section{Nazi Ideology, Propaganda, Consensus, And The Pursuit Of The Holocaust By Bullets}

In 1925 Adolf Hitler wrote Mein Kampf. In it he promoted a belief system that formed the basis of Nazi ideology, a combination of nationalism and negative eugenics that promoted the removal — at least isolation but preferably sterilization or extermination — of "inferiors" from a "superior" gene pool (Müller-Hill 1988:22). Of the many categories of "inferiors" Hitler identified, he particularly despised German Jews, whom he blamed for the Reich's loss of WW1, along with the great loss of German lives and land this defeat entailed (Lukacs 1997:65-75 cited in Brietman 2000:13). Hitler believed Germany lost the war because German Jews (descendants of "inferior" Eastern Europeans) had treasonously stabbed their own nation in the back by submitting to the Allies. The Jews did so, according to Hitler, to advance their own social and economic position, thus illustrating their moral inferiority. Hitler also believed there existed a cunning group of international Jewish financers whose machinations involved aspirations of worldwide economic domination. Whether rich or poor, powerful or powerless, inferior or cunning, German or otherwise, Jews, Hitler believed, posed a genetic and moral threat to the Western world. For Hitler, "the 'Jewish question' was the key to all other problems and hence [was] the ultimate problem" (Browning 2004:10).

From this basis arose another facet of Nazi ideology"Lebensraum"- the imperial quest to obtain more "living space." According to Hitler, if the Germanic race was to thrive, then the ten million or so ethnic Germans living across Europe needed to be repatriated. Together, Germany and Germans from near and far would become stronger. Here Nazi ideology drew on the tenants of positive eugenics: the adding of "superior" stock to a generally "superior" gene pool. To accommodate this anticipated influx, however, Germany (apparently) required more land. The need for more living space justified the Nazi regime's drive for war (Wistrich 2001:38). As far as Hitler [1925] (1943) was concerned, the needed land would best come from beyond the Reich's eastern border-Poland and the Soviet interior. Annexing other nations' lands and the unavoidable decimation of large numbers of their native populations hardly bothered Hitler, who saw Lebensraum as just another chapter in European colonialism (Browning 2004:14). Like Britain's empire, for Hitler, "The Russian space is our India" (2013:28). And, with a tip of the hat to formal rationality, why bother inefficiently travelling halfway across the world when a potential colonial empire lay next door? 
During the mid-1920s when Hitler published his vision, the Nazis were politically powerless. In 1928 the party pursued political office. However, many Germans found Hitler's anti-Semitic tirades offensive and the party won very few electoral seats. Having learnt from their mistakes, the Nazis adopted a new strategy. They reserved their distain of Jews for like-minded audiences and tailored their nationalistic message to appeal to the widest possible audience, telling voters whatever they wanted to hear. By the 1932 election the Nazi party won 37.3 per cent of the national vote (Wistrich 2001:44). This success was accentuated by the simultaneous disintegration of the larger left-wing parties, whose greater collective power was diminished by in-fighting (Bauer 2001:32). After political negotiations in 1933 Hitler was offered the chancellor's seat, and the Nazi party democratically ascended to power.

Because many Germans did not share the Nazi party's radical ideology or Hitler's animus toward the Jews, Nazi propagandist, Joseph Goebbels, was tasked with implementing broad attitudinal change. One particularly powerful strategy was to financially support those academics and scientists willing to become National Socialists (Friedlander 1995:126). This contractual clause inadvertently ensured that those most likely to obtain government funding were Nazi sympathisers or careerists likely to tow the party line. Both groups could be counted on to provide the Nazi regime with scholarly data that bolstered the party's radical belief system.

Some scholars, however, refused to become Nazis, or to tell the regime what it wanted to hear. These scholars were forced to take their dissenting voices elsewhere, or were silenced through imprisonment or execution (Westermann 2005:36). Between 1933 and 1934 about 1,600 Jewish academics were fired and replaced with no doubt grateful "Aryans" (Bracher 1970:269 cited in Markusen and Kopf 1995:212). Also in 1934, a law against political libel and slander criminalised political dissent, further suppressing criticism of the Nazi regime. Over time the voices of the German intelligentsia started echoing the Nazi regime. If all these influential figures seemed to agree with Hitler, then, in the eyes of ordinary Germans, perhaps Nazi ideology was not all that radical after all. Perhaps the party was even on the right track.

These (pseudo) scientific views, in conjunction with additional Nazi spin, were injected into the national educational curriculum, various Nazi youth organisations, the newspaper press, and the film industry. The last of these, for example, produced subsidised movies with titles like Jew Suess and The Eternal Jew. As Friedländer (2007:102) notes, the aim of both films was the same, "to elicit fear, disgust, and hatred." They had their intended effect. As one viewer noted, "The Jew is shown 
here as he really is [...] I would have loved to wring his neck" (quoted in Friedländer 2007:100). In the absence of any dissenting views, many ordinary Germans started feeling indifferently towards, or even started seeing merit in, Nazi ideology. Much like Milgram, his staff, and participants, many ordinary Germans came to feel justified in inflicting harm on other people. The means to this end were different (thus the different historical facts), but the end was the same: although the reason for inflicting harm differed, in both cases doing so was perceived to be important, even necessary.

As the popularity of Nazi ideology grew, how did the regime deal with Hitler's most despised "inferiors"-Germany's Jews? Between 1933 and 1941, two main factions on the Jewish question emerged. On the one hand, there were the "realists" who favoured legislative changes that promoted forced emigration (Schleunes 1970:216). And on the other, were those, like Goebbels, termed the "strong believers" (Wilhelm 1997:118), who thought that emigration would not stop these "inferiors" from reproducing just beyond the Reich's border. Thus, when dealing with any "inferior" group, they believed sterilisation or even extermination was the only permanent solution (Wilhelm 1997:118-119). For many years after 1933 Hitler favoured forced emigration, probably because it seemed more "realistic." Two events, both in 1938, reinforced this preference. First, the Kristallnact pogrom, a violent and destructive event organised by the Nazi's strong believers that generated numerous economic and political problems for Germany. Second, following Germany's annexation of Austria the low-ranking bureaucrat Adolf Eichmann showed emigration was possible by successfully deporting onequarter of all Austrian Jews in less than six months (Browning 1978:5). These two events cemented a pivotal power shift within the Nazi hierarchy through which the "hoodlums were banished and the bureaucrats took over" (Rubenstein 1978:27).

While Hitler's actions signified his support for the realists, his rhetoric still tended to reflect the views of the strong believers, stating on 30 January 1939 ,

At the time of my struggle for power, it was mostly the Jewish people who laughed at the prophecy that one day I would attain in Germany the leadership of the state and therewith of the entire nation, and that among other problems I would also solve the Jewish one. [...] Today I want to be a prophet again: If international finance Jewry inside and outside Europe again succeeds in precipitating the nations into a world war, the result will not be the Bolshevization of the earth and with it the victory of Jewry, but the annihilation of the Jewish race in Europe. (Quoted in Friedländer 1997:309-310). 
Such threats were in all likelihood both posture and genuine. Posturing, because even if the Nazis later gained control of Europe they had neither the strategy, nor the infrastructure, nor the technology-no procedure - to render them capable of exterminating such massive numbers of people. Annihilation was and would remain for some time impossible. However, the threat was not hollow, because although a means of massacring millions of civilians did not then exist, Hitler's past experience hinted at the possibility that, with time, it could be invented.

As a courier in the Wehrmacht during WW1, Hitler participated in about fifty battles (Victor 1998:55 cited in Rhodes 2002:28). Hitler experienced the Battle of the Somme, which killed or wounded more than a million men in less than six months (Middlebrook 2006). Many other high-ranking Nazis also experienced the destructive power of modern warfare. If death on such a massive scale were possible in one context, why not in another- just change the target and obtain the same end result? As Bartov argues,

[W]hile there is clearly a distinction to be made between the mutual killing of soldiers and the wholesale massacre of defenseless populations, it is crucial to realize that total war and genocide are closely related. For modern war provides the occasion and the tools, the manpower and the organization, the mentality and the imagery necessary for the perpetration of genocide. With the introduction of industrial killing to the battlefield, the systematic murder of whole peoples became both practical and thinkable: those who had experienced the former could imagine and plan, organize, and perpetrate the latter. (1996:50)

In fact, almost two decades earlier in Mein Kampf, Hitler had envisaged the application of the then-latest military technology to resolving his score with the Jews, suggesting that 12,000 to 15,000 "Hebrew corrupters" should be "held under poison gas" (quoted in Glover 1999:321). And Hitler knew that other nations during wartime had managed to exterminate massive numbers of unwanted civilians. Hitler "admired" the United States' extermination of its indigenous population (Toland 1976:203), and noted before the start of WW2, "Who still talks nowadays of the extermination of the Armenians?" (Quoted in Breitman 1991:43). As Germany, perhaps the most technically advanced nation in the world, approached the mid-twentieth century, who knew what might be possible under the cover of war. Perhaps they could pursue both war and genocide. Just as Milgram used the Holocaust as an initial guide to envision his basic experimental procedure, Hitler used previous genocides and wars to envision exterminating the Jews. 
Nevertheless, until 1939 all signals suggested to the "realist" in Hitler that extermination remained impossible, and Jewish emigration the more practical alternative. But the "strong believer" in Hitler knew that displacing "inferiors" beyond the border would not eliminate their perceived threat. Thus, a realistic strategy capable of mass extermination is, in all likelihood, what he ultimately desired. After all, underlings referred to the annihilation of European Jewry as "the Führer's wish"something most desirable but perhaps unobtainable (Fleming 1984:44). For "realist" bureaucrats-Eichmann, his superior Reinhard Heydrich, and his superior Heinrich Himmler-working competitively on the Jewish question, great reward awaited those who could convert the Führer's wish into reality. Thus, when Hitler expressed his desire, even rhetorically, for "the annihilation of the Jewish race in Europe," fawning underlings interpreted his statements as a Milgram-like preconceived goal in need of a procedural resolution. In such a context, formal rationality in the form of goal-orientated problem solving stepped to the fore.

Once the objective had been set, everything went on exactly as Weber, with his usual clarity, spelled out: "The "political master" finds himself in the position of the "dilettante" who stands opposite the "expert", facing the trained official who stands within the management of administration.' The objective had to be implemented; how this was to be done depended on the circumstances, always judged by the 'experts' from the point of view of feasibility and the cost of alternative opportunities of action. (Bauman 1989:15)

Though many scholars have argued that formally rational thought, bureaucracy, and modernity all played a role in the Holocaust (Bauman 1989; Aly and Heim 2002; Peukert 1993; Ritzer 1996), others who are generally supportive of the idea, have nonetheless highlighted a key limitation - all tend to equate modernity with technology:

The academic discourse on "modernity," though it has produced some brilliant work... has tended to overlook several characteristics of the murders themselves: that they were not carried out in a clean, factory-like manner, and that Nazi ideology preceded the "rationalized" structures which implemented it. (Stone, 1999:367 [italics added])

More specifically, beyond Auschwitz's factory of death, Wistrich (2001:224) notes that 40 per cent of Holocaust victims died after being worked, marched, starved and, perhaps most callously, shot to death during what Dawidowicz (1981:12) terms "primitive" mass shootings (see also Goldhagen 1996:10). Bloxham and Kushner (2005:155) refer to Pohl's (1997:405) research on the "de-bureaucratisation" of the Holo- 
caust, noting, "Neither can the murder by shooting in situ of millions of Polish, Soviet and Serbian Jews be described in any meaningful sense as a modern 'bureaucratic' process." As I show below, however, over time the shootings in Eastern Europe in fact demonstrate the kind of bureaucratic learning and development seen in Milgram's experiments twenty years later.

Early during the Soviet Invasion, Himmler and Heydrich perceived an opportunity to convert the "Führer's wish" into reality. They wanted Germans under their control to exterminate every Jewish man, woman, and child they encountered. ${ }^{1}$ However, with no previous experience in genocide - what Hitler asserted in March 1941 was to be a "war of extermination" (quoted in Mayer 1988:209 cited in Markusen and Kopf 1995:132) - Himmler and Heydrich did not yet know how the killing process might work, what leaders and units would prove effective, and whether the German rank and file would resist (Brietman 2000:44-45). Although Goebbel's propaganda campaign may have convinced many ordinary Germans of the necessity of eliminating "inferior" and "threatening" groups, it is one thing to agree with a general policy objective, but another matter to be directly involved in its execution-literally. And as far as killing went, Himmler knew "the execution of civilians might have damaging psychological effects" on his men, "even in 1940 he said he had been warned about this" (Breitman 2000:48). Here Breitman alludes to Germany's invasion of Poland in 1939, where Hitler feared the Polish intelligentsia would encourage Poles to resist German hegemony. The Führer therefore believed that securing Polish docility necessitated the elimination of the intelligentsia, and so Heydrich supplied his Einsatzgruppen forces with a list of 61,000 "anti-German" Poles (quoted in Rossino 2003:15). The Wehrmacht's usual wartime policy for dealing with civilian resistance was to capture those responsible and, if found guilty by a military court, shoot them. If resisters evaded capture, community leaders were taken hostage and their lives threatened if the partisan activity continued (Rossino 2003:13).

1. As Breitman (2000:44) said: "One reading of the events is that the Einsatzgruppen commanders already knew the final goal of Nazi Jewish policy and were given some discretion to accomplish as much as they could with limited manpower. Jewish males were considered a more immediate threat, and it was easier to find "reasons" (pretexts) to kill them." The alternative reading is that before the Soviet Invasion Himmler and Heydrich planned only to have the intelligentsia killed. However the successful killing of this group later emboldened them to expand the circle of victims until it encompassed all Jewish men, women, and children. See the Krausnick versus Streim debate (Breitman 1991:290). 
The German armed forces instructed to undertake these tasks employed the only method of execution they knew-death by firing squad. Polish victims faced a firing squad separated by about 10 meters or so and were shot (see Figure 3 below).

Figure 3: The execution of Father Piotr Sosnowski near Tuchola, Poland on October 27, 1939. ${ }^{2}$

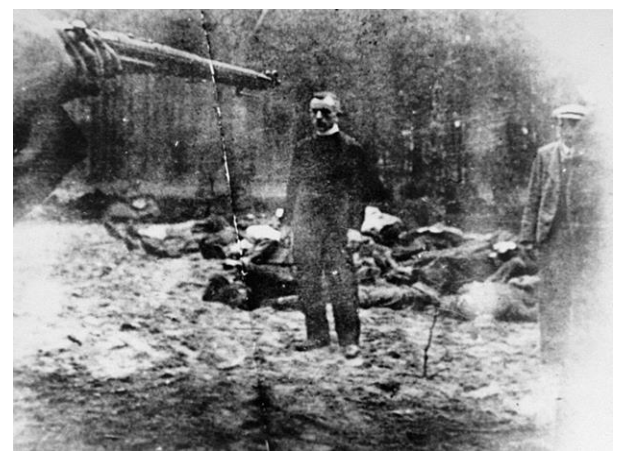

During these executions victims collapsed where they were shot (see Figure 3). Body disposal meant shooting squads were forced to directly confront — see and touch — the frightful wounds they had inflicted on defenceless civilians. According to Grossman, confronting a person one has just killed can accentuate the initial trauma (1995:112). Consequently, as the number of executions increased - sometimes up to ten Poles for every German life lost (Rossini 2003:129)—some executioners experienced what Lieutenant General Max Bock described as "vast agitation and powerful emotional stress" (quoted in Browning 2004:74). Some commanders believed these psychological problems were caused by the Polish hostages' frequently Germanic facial features. Victims occasionally included women and children, the latter proving particularly difficult to shoot (Westermann 2005:144).

Aware of the psychological problems generated by the executions, in June 1940 Himmler promoted the brutal WW1 veteran Oscar Dirlewanger and supplied him with a battalion of previously imprisoned poachers to undertake the kinds of executions he suspected most Germans would shy away from (Breitman 1991:129-130). But the enormous scale of the Soviet operation required the participation of more numerous ordinary Germans. Then again, in favour of Himmler and Heydrich's

2. https://www.ushmm.org/learn/students/learning-materials-and-resources/ poles-victims-of-the-nazi-era (access date: June 23, 2016). 
genocidal ambitions in the Soviet interior, it should be remembered that during the Polish invasion the German armed forces still shot about 16,000 civilians (Roseman 2002:24), and after capitulation, SS forces shot about 50,000 Poles (Rossino 2003:234). So during this campaign, at least some (perhaps many) Germans proved capable of regularly shooting defenseless men. Also, during the Soviet Invasion the victims would not be somewhat-Germanic-looking Poles, but mostly Soviet Jews, people who were ethnically, culturally, and economically very different from the Germans in Himmler's ranks and the main targets of nearly a decade of Nazi propaganda - Jewish Bolshevism.

Himmler need not have worried. When Germany invaded the Soviet interior on 22 June 1941, these ordinary men quickly proved to be proficient executioners of civilians.

There is something at once profoundly disturbing yet rapidly numbing in the narration of the anti-Jewish campaign that developed in the territories newly occupied by the Germans or their allies. History seems to turn into a succession of mass killing operations and, on the face of it, little else. [...] All there is to report, it seems, is a rising curve of murder statistics, in the North, the Center, the South, and the Extreme South. (Friedländer, 2007:240)

The Nazi regime went on to shoot about 1.4 million Jews (Hilberg 1980:93). In light of the psychological problems associated with killing mostly men during the Polish invasion, how during the Soviet Invasion did ordinary Germans prove so capable of massacring massive numbers of civilians?

Perhaps Nazi propaganda had been so successful that Germans viewed Soviet Jews as different people, even from Poles. More likely, Himmler and Heydrich had learned from the Polish campaign, and with intentions of encouraging, persuading, or if necessary, coercing their men into doing what they wanted, they approached the Soviet campaign with caution. Matthäus (2004:263) argues, "instead of providing explicit orders for the rapid expansion of the killing process, the SS and police leadership in Berlin seems to have followed a course that can be described as controlled escalation." Heydrich, in particular, had a "fear of going too far too quickly." Indeed, on the eve of the invasion the Einsatzgruppen and Order Police received the (purposefully?) ambiguous Commissar Order: "This struggle demands ruthless and energetic measures against bolshevist agitators, guerrillas, saboteurs, Jews, and complete elimination of any active or passive resistance" (quoted in Browning 2004:222-223). These orders escalated so that by 17 July they required that all Jews be shot (Streit 1994:108-109). If German execu- 
tioners willingly shot Jewish men, the leadership informed them that to eliminate the threat of revenge attacks against future Germans, they then had to kill the women and children too (Longerich 2012:539). In line with Heydrich's fear of going too far too soon, Himmler suspected that, "Once they [his men] had carried out mass murder in response to an alleged crime or provocation, it would be easier to get them to follow broader killing orders later" (Breitman 2000:48). To reinforce the necessity of the men's duties, Himmler and other senior SS officers visited their troops in the field. As Brietman (2000:51) observes, the leadership relied on "the weight of authority to override qualms of conscience or simple distaste for unpleasant tasks." There would be no compromises. As one officer noted, "Himmler issued an order stating that any man who no longer felt able to take the psychological stresses should report to his superior officer. These men were to be released from their current duties and would be detailed for other work back home" (Quoted in Klee, Dressen and Riess 1988:82). This seemingly attractive option, however, was an "evil trick" designed to highlight "weak" officers (quoted in Klee et al. 1988:82). This officer also suspected (correctly) such declarations of softness would preclude all subsequent promotional opportunities (see Westermann 2005:208). Despite this threat, replacing men because of psychological stress was fairly common (Klee et al. 1988:60).

Over time Himmler's replacement policy actually had an unanticipated effect. As Hannah Arendt noted, the gradual attrition of those who could not handle shooting civilians led to a concentration of men who could (Naumann 1966:xxvii). Therefore, those "ordinary men" who remained differed from those "ordinary men" who dropped out in that the former were not just willing but also able. They became the "DauerSchützen"-permanent shooters (Kwiet 1998:18). Although these hardened Germans were less emotional, they were not emotionless-many found the seemingly endless shootings stressful (Klee et al. 1988:67).

Limiting the effectiveness of these kinds of coercive techniques was that the leadership's mere words in no way affected the physical determinants of the stress that shooting other humans at close range could cause. As we shall see, more effective at easing the shooting squads' stress and consequently accelerating the "rising curve of murder statistics" was their application of formally rational thought: problem solving ideas that emerged with increasing time and observational experience. Like the top-down and bottom-up interactions between Milgram and his pilot study participants (who looked away from their visible victim inspiring Milgram to introduce a stress-reducing and completion-rateincreasing wall into his basic procedure); top-down and bottom-up interactions between the field leadership and their shooters saw the rational 
discovery of a less stressful and more efficient "one best way" of shooting civilians.

Although, "[e]very...squad had its preferred methods" (Poliakov 1979:123 cited in Markusen and Kopf 1995:134), after "lessons learned" (Kwiet 1998:10), certain innovators in the field discovered less stressful, more efficient ways to shoot civilians. Then following "frequent information exchanges" these ideas spread to other shooting squads (Kwiet 1998:10). What follows is a general overview of the transition from inefficient and strain-inducing shooting techniques to more efficient and strain-resolving methods of executing civilians en masse.

In response to apparent sniper attacks, between 24 and 27 June 1941, Einsatzkommando Tilsit undertook three separate mass executions of 526 (mostly Jewish) Lithuanian men (Kwiet 1998:4; 6). This signalled the start of the Holocaust in the Soviet Union (Brietman 2000:43). Already the shooting method used differed from that deployed in Poland (Figure 3) in that a burial site was first selected, perhaps a hill-shaped land formation, a ravine, or in this case, a tank trap. The victims were then instructed to stand on the grave's edge so that when they were shot, most fell into the pit. For the shooters, their victims' bodies quickly and conveniently disappeared from view (Musmanno 1961:76). The execution squad thus avoided the proximate consequences of their actions. Burial took place rapidly and the squad moved on. To save having to search for such a site, an even more efficient approach was to force victims to dig their own graves.

Figure 4: "Jewish men are forced to dig their own graves before being executed." $" 3$

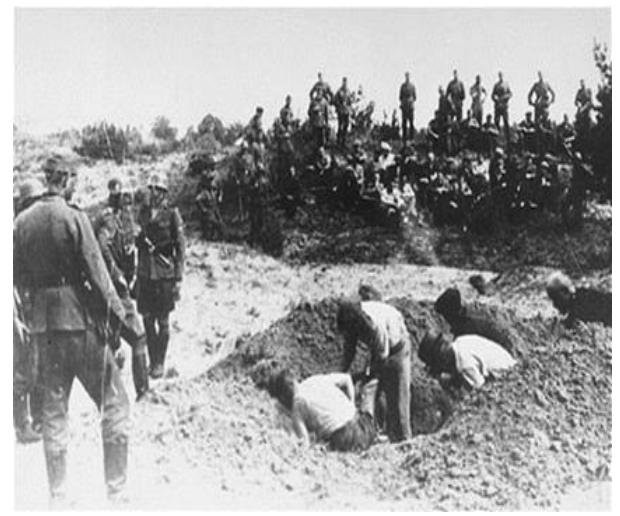

3. See http://www.historyplace.com/worldwar2/holocaust/h-einz-42.htm (access date: September 12, 2008). 
At Einsatzkommando Tilsit's first execution on 24 June, and after securing the burial site, the condemned were instructed to walk towards the tank trap. On arrival,

A group of ten men was forced to take up position at the edge of the pit with their faces turned toward the execution commando. The twenty-man strong firing party stood at a distance of twenty meters from the pit's edge. Two marksmen aimed their rifles at one victim, an SS officer gave the order to shoot. After each round a new group was driven to the edge of the pit and forced to push into it any corpses that had not fallen in on their own. (Kwiet 1998:7 [italics added])

Some of these executioners started to show signs of "softness," succumbing "to feelings of nausea and nervous tension" (Kwiet 1998:20). Himmler and Heydrich's suspicions were confirmed, with their orders generating what the men in the field termed Seelenbelastung"burdening of the soul" (Hilberg 1980:91). During Einsatzgruppe C's first execution, a more proximate yet otherwise similar shooting technique was relied upon. As one shooter noted, "In Rovno I had to participate in the first shooting. [...] Each member of the firing-squad had to shoot one person. We were instructed to aim at the head from a distance of about ten metres" (Quoted in Klee et al. 1988:62). After firing at about five people, he stopped due to "nervous strain" (quoted in Klee et al. 1988:62). To alleviate the soldiers' strain the shooting method was changed: several shooters were tasked with firing at each victim. At an execution on 12 July 1941, however, one shooter noted a problem with this technique. "Six of us had to shoot them. The job was assigned thus: three at the heart, three at the head. I took the heart. The shots were fired and the brains whizzed through the air. Two in the head is too much. They almost tear it off" (Quoted in Klee et al. 1988:97). Despite the disturbing visual spectacle, some commanders, like Otto Ohlendorf, preferred this method because it helped "avoid any individual having to take direct, personal responsibility" (quoted in Klee et al. 1988:60).

Despite the introduction of these strain-resolving techniques, executioners and squad leaders could still not avoid seeing their victims at close range just before and during shootings. Bauman (1989:26) suggests that the shooters were therefore inclined to distance themselves as far as possible from the civilians. Doing so, however, created a problem: less accurate shooting resulted in wounded, or in some cases, unwounded civilians falling into the graves with the dead. These victims were buried alive. Some would try to claw their way out. Field leaders demanded changes to the technique, which they believed to be abhorrent (Musmanno, 1961:82). To improve accuracy shooters had to move closer to their 
victims. But the closer they got the more they could see and hear, thus intensifying the psychological burden. As they moved closer to their victims, a new and popular shooting technique emerged: to alleviate shooter strain the victims were now instructed to turn away from the shooters, thus eliminating eye contact between the two groups. Additionally, some squads instructed their victims to kneel, lowering their centre of gravity over the precipice so that they were more likely to fall forward into the grave below. The risk of the shooters later having to push (touch and see) any victims who failed to fall into the grave was reduced.

\section{Figure 5: "An Einsatzgruppe during the execution of Soviet civilians in} Kraigonev, USSR. Summer 1941."4

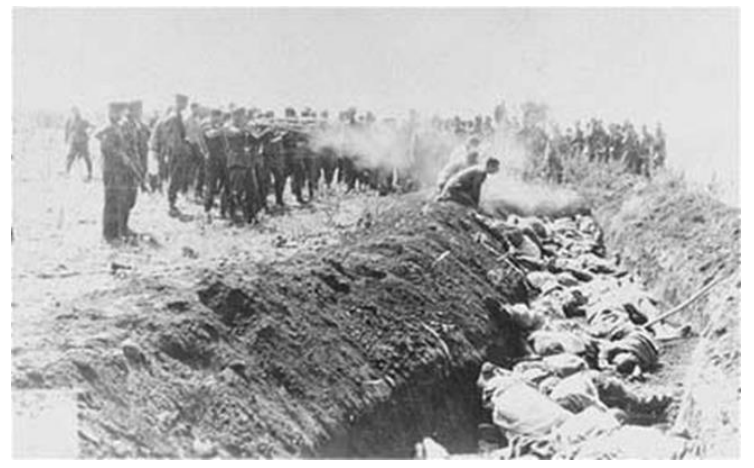

Still, the method was not without problems. Sometimes victims' sculls would shatter when hit at fairly close range by bullets from high-powered rifles, a sight the shooters could not avoid (see Goldhagen 1996:280). In response, the neck-shot emerged as the "recommended shooting technique" (Goldhagen 1996:217). The neck-shot required victims turn away from the executioner or lie face-down on the ground. From point-blank range, the shooter fired a single shot into the nape of the neck (just above the shoulders). The bullet would enter the back of the neck presumably producing a small entrance wound and, on severing the victim's spinal cord, kill them instantly.

4. See http://www.nachfolgeprozesse.nuernberg.de/english/trials/trials10.html (access date October 3, 2008). 
Figure 6: An execution of Jews by an Einsatzkommando in Kovno (Berenbaum 1997:115).

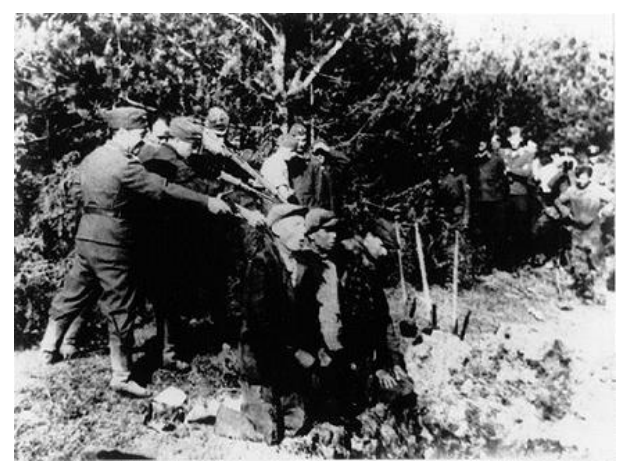

With the neck-shot executioners could avoid having to see the larger exit wound. Compared to previous techniques, the neck-shot was relatively clean and because it killed instantly, perceived by many Germans as a more humane way of killing (see Klee et al. 1988:201). This new shooting technique enabled a larger proportion of ordinary Germans to participate in the killings, thus adding to the "rising curve of murder statistics."

The next major innovation after the neck shot was Friedrich Jeckeln's "Sardinenpackung" technique, which emerged near the end of July 1941. August Meier describes the technique:

I still particularly recall an Aktion in Schepetovka which stands out in my mind as extraordinarily gruesome. It involved about a hundred people. Women and children were among those shot. Jeckeln said: 'Today we'll stack them like sardines.' The Jews had to lie layer upon layer in an open grave and were then killed with neck shots from machine pistols, pistols and rifles. That meant they had to lie face down on those previously shot [whereas] in other executions they were shot standing up and fell into the grave or were dragged in. (Quoted in Wilhelm, 1991:231 cited in Rhodes 2002:114)

Between late June and the end of August 1941 Jeckeln's men shot 44,125 civilians (Hilberg 1961:196); a figure that exceeded those of all other police units (Büchler 1986:17). With time Jeckeln's technique advanced.

In September 1941, the Jewish community in Kiev was instructed to meet at $8 \mathrm{am}$ at a downtown location. All were to bring official documents, clothing, linen, and valuables. The Jews were told that those who failed to show up would be hunted down and shot. On the appointed day, a large crowd gathered. Germans along with Ukrainian collaborators ar- 
ranged the Jews into a staggered line and forced them in the direction of the nearby Babi Yar ravine. A truck driver describes the scene:

The Ukrainians led them past a number of different places where one after the other they had to remove their luggage, then their coats, shoes and overgarments and also underwear. They also had to leave their valuables in a designated place. There was a special pile for each article of clothing. It all happened very quickly and anyone who hesitated was kicked or pushed by the Ukrainians to keep them moving. (Quoted in Klee et al. 1988:63)

Then, according to another eyewitness, "in tight columns of one hundred each" the Jews "were marched to the adjoining Babi Yar" ravine (quoted in Korey 1993:63). The ravine,

was about 150 metres long, 30 metres wide and a good 15 metres deep. Two or three narrow entrances led to this ravine through which the Jews were channeled. When they reached the bottom of the ravine they were seized by members of the Schutzpolizei and made to lie down on top of the Jews who had already been shot. This all happened very quickly. The corpses were literally in layers. [...] When the Jews reached the ravine they were so shocked by the horrifying scene that they completely lost their will. It may even have been that the Jews themselves lay down in rows to wait to be shot. [...] there was a 'packer' at either entrance to the ravine. These 'packers' were Schutzpolizisten, whose job it was to lay the victim on top of the other corpses so that all the marksman had to do as he passed was fire a shot. (Höfer quoted in Klee et al. 1988:64-66)

At the Babi Yar massacre, Jeckeln developed an organised process of mass murder. He attached his innovation to the end of what over just a few months had evolved into an inherently bureaucratic, assembly line process complete with specialist functionaries - cordoning, collecting, packing, shooting duties. In his report to Berlin Jeckeln tersely noted, "Special commando 4a, together with Einsatzgruppe C Headquarters and two commando groups of the South Police Regiments, executed 33,771 Jews in Kiev on 29 and 30 September 1941" (Quoted in Lozowick 1987:236). A secret official report further noted that the key to this staggering result was Jeckeln's application of some "extremely clever organization" to overcome the usual "difficulties resulting from such a large-scale action" (Korey 1993:62). The Nazi regime's discovery of the most efficient, "one best way" of using firearms to arrive at preconceived goal achievement took place over time and through experience. As Lozowick observes, "It seems no accident that the orderly, well-planned murder of 33,000 Jews took place at Kiev at the end of this period, rather than at Lvov near the beginning" (1987:236). 
One other important innovation, developed elsewhere and only later added to Jeckeln's technique, was to substitute German shooters with Eastern European collaborators, especially when killing women and children (see Matthäus 2004:275). As one Einsatzgruppe A member stated,

The orders for the third or fourth Einsatz...gave instructions for members of the local population to be used to carry out the actual dirty work, to which end special units should be set up. The purpose of this measure was to preserve the psychological equilibrium of our own people.... (quoted in Klee et al. 1988:81 [italics added]).

Local collaborators, the "end special units" (that is, the last and most stressful link in the destructive bureaucratic chain), were responsible for producing some of the bleakest statistics. For example, on 1 December 1941 Einsatzkommando 3's leader Karl Jäger presented his superiors in Berlin with a ledger denoting nearly 140,000 mostly Jewish women and children killed between 7 July and 25 November (Friedländer 2007:362). In his report, Jäger explained how he managed to achieve such an astounding statistic: "Following the formation of a raiding squad under the command of...Hamann and 8-10 reliable men from the Einsatzkommando the following actions were conducted in cooperation with Lithuanian partisans" (Quoted in Klee et al. 1988:46). As MacQueen concludes, Jäger's “"achievement” has to be considered largely as a triumph of managing the Lithuanian Schutzmannschaft forces (some 8,000 men by the end of 1941) and the Lithuanian Police, without whom this deadly work would not have been remotely possible" (1997:100).

By December 1941 even Jeckeln was supplementing his specialist German marksmen with a rapid rotation of locals, in this case Latvians (Angrick and Klein 2009:156). It seems, then, the German authority's most popular strategy to prevent their execution squads from becoming "neurotics or savages" (SS and Police Leader Bach-Zelewski quoted in Hilberg 1961:218) was the one that physically most shielded Germans from any perceptual engagement. As one police interpreter stated, "It was only in the early days that members of our section had to man the firing-squad. Later we had a Kommando of Latvians who made up the firing-squad" (quoted in Klee et al. 1988:126). Like Milgram during his Truly Remote pilot study, the German field leadership discovered that the best way to achieve their preconceived goal was to ensure the harm inflictors could perceptually circumvent (avoid) confronting the harmful consequences of their contributions.

The application of Jeckeln's "controlled" shooting process and the "calculable" result of killing 15,000 people per day became "predictable". As a result, this "efficient" outcome became - should the Nazi 
leadership desire it—repeatedly obtainable. ${ }^{5}$ Over time Jeckeln's “factory-orientated approach" (Angrick and Klein 2009:134) advanced all four of Ritzer's components of a formally rationalised system (see Russell 2009). Far from "de-bureacratization," Jeckeln's shooting process, which included division of labour, specialisation, clear responsibilities, written records, rules and procedures, and impersonal relations, resulted in an increasingly bureaucratic escalation of the execution process on the Eastern Front. The Babi Yar massacre, in particular, can, I believe, be described as a modern bureaucratic process. Formally rational problem solving and bureaucratic organisation therefore helps us to better understand the "rising curve of murder statistics" during the first few months of the Soviet campaign because, as Weber argues, "The decisive reason for the advance of bureaucratic organization has always been its purely technical superiority over any other form of organization. The fully developed bureaucratic mechanism compares with other organizations exactly as does the machine with the non-mechanical modes of production" (Gerth and Mills 1946:214).

Despite these destructive innovations, Jeckeln was informed by Himmler in December 1941 that, the mass shootings were overly complicated and were psychologically too difficult for their men. Himmler thought liquidating civilians with gas vans would probably be best (Angrick and Klein 2009:152). Gassing had already started to go through a remarkably similar trial-and-error journey of discovery, from the T4 Euthanasia project through to the Chełmno, Belzec, Sobibor, and Treblinka extermination camps. Each innovation along the way contributed cumulatively to the development of the "one best way" of gassing and disposing of what became massive numbers of civilians at the Auschwitz-Birkenau gassing factories. Once victims were trapped in Auschwitz's hermetically sealed industrial gas chambers, little of their fate was detectable by those outside. As prisoner Karl Lil put it, "A few seconds later a cry, muffled, stifled by the concrete walls. And then, a few minutes afterward, a brownish-yellow vapor poured out of the chimney" (quoted in Naumann 1966:249). Because at Auschwitz the most directly involved Germans could be, if they so chose, physically and emotionally distant from the act of killing, it had become much easier for the leadership to persuade, tempt, or coerce ordinary Germans into participating in harm infliction.

5. Using Jeckeln's Babi Yar technique, on 3-4 November 1943 SS and Police Leader Friedrich Krüger and his men shot 43,000 Jews in the largest mass shooting undertaken by Germans during WW2 (Arad 1987:365-369). 


\section{Conclusion}

Since the mid-1960s critics of the Milgram-Holocaust linkage have listed the many differences between the Obedience studies and the Holocaust in an attempt to render any connection externally invalid. One of these more salient differences is that most Germans who refused to shoot Jews did so because of sheer physical revulsion (see Browning 1992:7475). However, nearly all of Milgram's participants refused to harm their victim on ethical grounds: "I don't think it's right" (Russell, 2009:273). It is therefore argued that the Obedience experiments and the Holocaust are totally different and thus incomparable. I disagree.

Instead, I suspect the Obedience studies and the Holocaust share certain commonalities that are so important that they are capable of negating the above kind of differences. Two such commonalities are that both Milgram and the Nazi innovators (1) shared the same preconceived goal (ensure most ordinary people inflicted harm on others), and (2) they both applied formally rational techniques of discovery and organisation to overcome any obstacles that got in the way of achieving their shared goal. Many Germans refused to shoot Jews because they found it revolting, and as shown, certain Nazi innovators used rational techniques of discovery and organizational processes to scale this obstacle interfering with goal achievement. Many of Milgram's participants refused to shock the learner because they thought it was unethical to do so, and as shown, Milgram used rational techniques of discovery and organizational processes to scale this obstacle interfering with goal achievement. Therefore, it may not matter that different obstacles were encountered-or even different paths pursued - during their quest to arrive at the same destination. As far as goal achievement is concerned, what is important is that both parties used the same formally rational tools to find a wayany way - of converting most ordinary people into willing inflictors of harm. ${ }^{6}$ In terms of different paths because of different obstacles, it should be remembered that there is more than "one best way" of rationally skinning a cat, so to speak. So in conflict with the present consensus, even among Milgram's strongest advocates, that the Obedience studies have only minor explanatory power when applied to the Holocaust (see Russell and Gregory 2015:128-130), I suspect the Milgram-Holocaust linkage is even stronger than previously imagined.

6. Actually, in terms of the squeamishness versus ethics obstacles, both the Nazi innovators and Milgram arrived at the same solution: both eventually put a wall up between cause and effect. 


\section{REFERENCES}

Aly, Götz and Susanne Heim. 2002. Architects of annihilation: Auschwitz and logic of destruction. Princeton, NJ: Princeton University Press.

Angrick, Andrej. and Peter Klein. 2009. The "Final Solution" in Riga: exploitation and annihilation, 1941-1944. New York: Berghahn Books.

Arad, Yitzhak. 1987. Belzec, Sobibor, Treblinka: the Operation Reinhard death camps. Bloomington, IN: Indiana University Press.

Bartov, Omer. 1996. Murder in our midst: the Holocaust, industrial killing, and representation. New York: Oxford University Press.

Bauer, Yehuda. 2001. Rethinking the Holocaust. New Haven, CT: Yale University Press.

Bauman, Zygmunt. 1989. Modernity and the Holocaust. Ithaca, NY: Cornell University Press.

Berenbaum, Michael. (Ed.). 1997. Witness to the Holocaust. New York: Harper Collins Publishers.

Blass, Thomas 1993. Psychological perspectives on the perpetrators of the Holocaust: the role of situational pressures, personal dispositions, and their interactions. Holocaust and Genocide Studies 7(1):30-50.

Blass, Thomas 2004. The man who shocked the World: the life and legacy of Stanley Milgram. New York: Basic Books.

Bloxham, Donald and Tony Kushner. 2005. The Holocaust: Critical Historical Approaches. Manchester: Manchester University Press.

Breitman, Richard. 1991. The architect of genocide: Himmler and the final solution. New York: Alfred A. Knopf.

Breitman, Richard. 2000. Official secrets: what the Nazis planned, what the British and Americans knew. London: Penguin Books.

Browning, Christopher. 1978. The final solution and the German Foreign Office: A study of Referat D III of Abteilung Deutschland 1940-43. New York: Holmes and Meier.

Browning, Christopher. 1992. Ordinary men: Reserve Police Battalion 101 and the final solution in Poland. New York: Harper Collins.

Browning, Christopher. 2004. The origins of the final solution: the evolution of Nazi Jewish policy, September 1939 - March 1942. Lincoln, NE: University of Nebraska Press.

Büchler, Yehoshua. 1986. Kommandostab Reichsführer-SS: Himmler's personal murder brigades in 1941. Holocaust and Genocide Studies 1(1):11-25.

Dawidowicz, Lucy. 1981. The Holocaust and the Historians. Cambridge, Mass: Harvard University Press.

Fleming, Gerald. 1984. Hitler and the final solution. Berkeley, CA: University of California Press. 
Friedlander, Henry. 1995. The origins of Nazi genocide: from euthanasia to the final solution. Chapel Hill, NC: University of North Carolina Press.

Friedländer, Saul. 1997. Nazi Germany and the Jews: The Years of Persecution, 1933-1939 (volume 1). New York: Harper Collins Publishers.

Friedländer, Saul. 2007. Nazi Germany and the Jews: The Years of Extermination (volume 2). New York: Harper Perennial.

Gerth, Hans and C. Wright Mills. 1946. From Max Weber: essays in sociology. New York: Oxford University Press.

Glover, Jonathan. 1999. Humanity: A moral history of the twentieth century. London: Pimlico.

Goldhagen, Daniel. 1996. Hitler's willing executioners: ordinary Germans and the Holocaust. London: Alfred A. Knopf.

Grossman, David. 1995. On killing: the psychological cost of learning to kill in war and society. Boston: Little Brown.

Hilberg, Raul. 1961. The destruction of the European Jews. Chicago: Quadrangle Books.

Hilberg, Raul. 1980. The anatomy of the Holocaust. In The Holocaust: ideology, bureaucracy, and genocide (the San José Papers), edited by H. Friedlander and S. Milton, 85-94. Millwood, NY: Kraus International Publications.

Hitler, Adolf. 1943. Mein kampf. Boston, Houghton Mifflin Company.

Hitler, Adolf. 2013. Hitler's Table Talk 1941-1944: Secret Conversations. H. R. Trevor-Roper, \& G. L. Weinberg (Eds.). New York: Enigma Books.

Klee, Ernst, Willi Dressen and, Volker Riess. 1988. "The good old days": the Holocaust as seen by its perpetrators and bystanders. New York: Free Press.

Korey, William. 1993. A Monument Over Babi Yar. In The Holocaust in the Soviet Union: Studies and Sources on the Destruction of the Jews in the Nazi-Occupied Territories of the USSR, 1941-1945. Edited by L. Dobroszycki and J. S. Gurock, 61-74. Armonk, NY: M. E. Sharpe.

Kwiet, Konrad. 1998. Rehearsing for Murder: the Beginning of the Final Solution in Lithuania in June 1941. Holocaust and Genocide Studies 12(1):326.

Longerich, Peter. 2012. Heinrich Himmler. Oxford, UK: Oxford University Press.

Lozowick, Yaakov. 1987. Rollbahn Mord: the early activities of Einsatzgruppe C. Holocaust and Genocide Studies 2(2):221-241.

Lutsky, Neil. 1995. When is 'obedience' obedience? Conceptual and historical commentary. Journal of Social Issues 51(3):55-65.

MacQueen, Michael. 1997. Nazi policy towards the Jews in Reichskommissariat Ostland, June-December 1941: from white terror to Holocaust in Lithuania. In Bitter legacy: confronting the Holocaust in the USSR, edited by Z. Gitelman, 91-103. Indianapolis, IN: Indiana University Press. 
Markusen, Eric and David Kopf. 1995. The Holocaust and strategic bombing: Genocide and total war in the twentieth century. Boulder, CO: Westview Press.

Matthäus, Jürgen. 2004. Operation Barbarossa and the onset of the Holocaust, June-December 1941. In The origins of the final solution: the evolution of Nazi Jewish policy, September 1939-March 1942, edited by C. R. Browning, 248-308. Lincoln, NE: University of Nebraska Press.

Middlebrook, Martin. 2006. The First Day on the Somme. Barnsley, U.K.: Pen and Sword.

Milgram, Stanley. 1963. Behavioral study of obedience. Journal of Abnormal and Social Psychology 67(4):371-378.

Milgram, Stanley. 1965. Some conditions of obedience and disobedience to authority. Human Relations 18(1):57-76.

Milgram, Stanley. 1973, December. The perils of obedience. Harper's, 62-66, 75-77.

Milgram, Stanley. 1974. Obedience to authority: an experimental view. New York: Harper and Row.

Miller, Arthur. 1986. The obedience experiments: a case study of controversy in social science. New York: Praeger.

Miller, Arthur. 2004. What can the Milgram obedience experiments tell us about the Holocaust? Generalizing from the social psychology laboratory. In The social psychology of good and evil, edited by A. G. Miller, 193-237. New York: Guilford Press.

Müller-Hill, Benno. 1988. Murderous science: elimination by scientific selection of Jews, Gypsies, and others, Germany 1933-1945. New York: Oxford University Press.

Musmanno, Michael. 1961. The Eichmann Kommandos. London: Peter Davies.

Naumann, Bernd. 1966. Auschwitz. New York: Praeger.

Parker, Ian. 2000. Obedience. Granta: The Magazine of New Writing 71:99125.

Perry, Gina. 2012. Beyond the Shock Machine: The Untold Story of the Milgram Obedience Experiments. Melbourne: Scribe.

Peukert, Detlev. 1993. The genesis of the "Final Solution" from the spirit of science. In Reevaluating the Third Reich, edited by T. Childers and J. Caplan, 234-252. New York: Holmes \& Meier.

Pohl, Dieter. 1997. Nationalsozialistische Judenverfolgung in Ostgalizien 1941-1944: Organisation und Durchführung eines staatlichen Massenverbrechens. Munich: Oldenbourg.

Rhodes, Richard. 2002. Masters of death: the SS-Einsatzgruppen and the invention of the Holocaust. New York: Alfred A. Knopf.

Ritzer, George. 1996. The McDonalidization of Society: An Investigation into the Changing Character of Contemporary Social Life (Revised Edition). Thousand Oaks, California: Pine Forge Press. 
Ritzer, George. 2015. The McDonalization of Society (8th Ed.). Los Angeles, CA: Sage.

Roseman, Mark. 2002. The villa, the lake, the meeting: Wannsee and the final solution. London: Penguin Press.

Rossino, Alexander. 2003. Hitler strikes Poland: blitzkrieg, ideology, and atrocity. Lawrence, KS: University Press of Kansas.

Rubenstein, Richard. 1978. The cunning of history: the Holocaust and the American future. New York: Harper Collins.

Russell, Nestar. 2009. Stanley Milgram's Obedience to Authority Experiments: Towards an Understanding of their Relevance in Explaining Aspects of the Nazi Holocaust. PhD thesis: Victoria University of Wellington.

Russell, Nestar. 2011. Milgram's obedience to authority experiments: Origins and early evolution. British Journal of Social Psychology 50(1):140162.

Russell, Nestar. 2014. The emergence of Milgram's bureaucratic machine. Journal of Social Issues 70(3):409-423.

Russell, Nestar and Robert Gregory. 2015. The Milgram-Holocaust Linkage: Challenging the Present Consensus. State Crime Journal 4(2):128-153.

Schleunes, Karl. 1970. The twisted road to Auschwitz: Nazi policy toward German Jews, 1933-1939. Chicago: University of Illinois Press.

Stone, Dan. 1999. Modernity and violence: theoretical reflections on the Einsatzgruppen Journal of Genocide Research 1(3):367-378.

Streit, Christian. 1994. Wehrmacht, Einsatzgruppen, Soviet POWs and antiBolshevism in the emergence of the final solution. In The final solution: origins and implementation, edited by D. Cesarani, 103-118. New York: Routledge.

Toland, John. 1976. Adolf Hitler. New York: Doubleday and Company, Inc.

Westermann, Edward. 2005. Hitler's police battalions: enforcing racial war in the east. Lawrence, KS: University Press of Kansas.

Wilhelm, Hans-Heinrich. 1997. "Inventing" the Holocaust for Latvia. In Bitter legacy: confronting the Holocaust in the USSR, edited by Z. Gitelman, 104-122. Bloomington, IN: Indiana University Press.

Wistrich, Robert. 2001. Hitler and the Holocaust: how and why the Holocaust happened. Toronto, ON: Random House of Canada Limited.

Nestar Russell teaches sessionally in the Department of Sociology at the University of Calgary. Currently he is writing book that, in greater detail, delineates the argument presented in this article. Nestar thanks to Robert Gregory, Hilary Earl, Simone Gigliotti, and Tim Pearson for their comments on drafts of this article. All responsibility rests with the author.

E-Mail: nestar.russell@gmail.com 